\title{
Study of Problem Identification and Solution for Handling the Housing Stimulant Grant Program in the COVID-19 Pandemic: A Case Study in Muncan Village, Bali
}

\author{
Ni Luh Putu Juniartini ${ }^{1}$, I Ketut Suwantara ${ }^{2}$, I Nyoman Anom Fajaraditya Setiawan ${ }^{3}$ \\ ${ }^{1}$ Tenaga Fasilitator Lapangan (TFL) Satuan Kerja Non Vertikal Tertentu (SNVT), Kementerian \\ Pekerjaan Umum dan Perumahan Rakyat (PUPR). \\ ${ }^{2}$ Balai Penelitian dan Pengembangan Perumahan Wilayah II Denpasar, Puslitbangkim, \\ Balitbang, Kementerian Pekerjaan Umum dan Perumahan Rakyat. \\ ${ }^{3}$ STMIK STIKOM Indonesia. \\ Email: 1juniraditya@gmail.com, ${ }^{2}$ arswandari@gmail.com, ${ }^{3}$ anomkojar@stiki-indonesia.ac.id
}

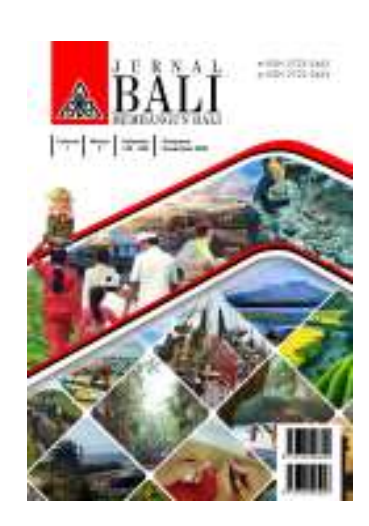

Article History

Received on 15 July 2020

Revised on 18 July 2020

Accepted on 11 Agustus 2020

\section{Abstract}

Purpose: The housing rehabilitation program for low-income people is carried out by the Indonesian Ministry of Public Works and Public Housing. Muncan Village is one of the areas that received 2020 house rehabilitation assistance (BSPS) for Karangasem Regency.

Research methods: Preventive measures are needed, especially for the Field Facilitator Team as the front guard, so that the BSPS program channelled adequately. The key to smooth distribution, in addition to the precise mechanism, must also follow the government's recommendations and implement health protocols.

Findings: Constraints on distribution activities, starting from November 2019 to the initial process in April 2020. Field constraints, social aspects, education, and the community's situation become challenges in these activities. But beginning in 2020 , the COVID-19 pandemic made the distribution of aid even more complicated with adjustments to the rules and recommendations of the government in conducting activities.

Implications: Additional mission the field team to accelerate the handling of the pandemic, an appeal about anticipating COVID-19 also needs to convey. Strategies related to initiatives provide a masker for beneficiaries to foster protocol awareness and motivation regarding applicable rules.

Keywords: identification, housing, pandemic, COVID-19, Muncan.

\section{Abstrak}

Tujuan: Program rehab rumah kepada masyarakat berpenghasilan rendah oleh Kementerian Pekerjaan Umum dan Perumahan Rakyat Indonesia. Desa Muncan merupakan salah satu daerah yang mendapat penyaluran bantuan rehab rumah (BSPS) tahun 2020 untuk Kabupaten Karangasem.

Metode penelitian: Diperlukan langkah preventif terutama untuk Tenaga Fasilitator Lapangan sebagai garda terdepan, agar program BSPS dapat tersalurkan dengan baik. Kunci kelancaran penyaluran, selain mekanisme resmi, harus pula mengikuti anjuran pemerintah dan menjalankan protokol kesehatan.

Temuan: Kendala pada aktifitas penyaluran, terhitung dari November 2019 sampai proses awal pada April 2020. Kendala lapangan, aspek sosial, edukasi, dan situasi masyarakat menjadi tantangan pada aktifitas tersebut. Namun mengawali tahun 2020, pandemi COVID-19 membuat penyaluran bantuan menjadi semakin rumit dan kompleks dengan adanya penyesuaian aturan serta anjuran pemerintah dalam melakukan aktifitas.

Implikasi: Misi tambahan bagi tim lapangan untuk percepatan penanganan pandemi, himbauan tentang antisipasi COVID-19 juga perlu disampaikan. Strategi terkait inisiatif, memberikan masker kepada penerima bantuan untuk menumbuhkan kesadaran protokol dan motivasi tentang aturan yang berlaku.

Kata kunci: identifikasi, rumah, pandemi, COVID-19, Muncan. 


\section{INTRODUCTION}

Eligibility in a house is certainly everyone's hope and indeed become one of the priorities for the owner of the house. Homes as one (or the third) needs of the three categories of human needs (food, clothing, and shelter) certainly have aspects of feasibility considerations and development criteria for achieving the level of comfort and safety of buildings. The feasibility aspects of housing construction are closely related to building foundations, building structures and other elements that interrelated in the construction process as a basis for consideration of the feasibility of a building. The feasibility issue refers to the legislation from the government through the Ministry of Public Works and Public Housing (Perkerjaan Umum dan Perumahan Rakyat/PUPR) as well as the rules issued by the World Health Organization (WHO) on healthy homes.

Concerning appeals and eligibility rules, PUPR has launched a program phase aimed at increasing livability in building community homes throughout Indonesia through the Housing Stimulant Grant Program (Bantuan Stimulan Perumahan Swadaya/BSPS). The discussion on the feasibility of the building will focus on case studies in Muncan Village, Karangasem Regency, Bali Province. In general, the BSPS is a government program with the hope of a positive impact in its implementation. The BSPS program has a process flow of activities directly to the field by assigning a Field Facilitator Staff (Tenaga Fasilitator Lapangan/TFL), recording actual and factual conditions of the area including recording the target of the Prospective Beneficiaries (Calon Penerima Bantuan/CPB) through continuous observation, interviews, and documenting the real situation. Direct interaction, especially by the TFL in the community at each location, the entire data collection must be carried out. The interaction aims to validate the data validity of CPBs, as well as exceptional communication and coordination with elements of regional governance such as village service structures, including those relating to local social and cultural conditions.

Data collection in the BSPS program carried out before entering the 2020 budget year, the initial activities related to the field verification process on CPB based on data and recommendations in each region. There is a common obstacle that occurs in the field situation, which has a majority of different conditions of education, abilities and understanding. However, entering 2020 
without being able to be predicted, events that had a global impact emerged with the COVID-19 pandemic and made the situation more severe in completing general obstacles and new obstacles encountered in the field. The COVID-19 pandemic forced people to follow various government recommendations, especially regarding health as a protection against this global pandemic. Obligations and risks become essential considerations in the region, especially in the Muncan Village in the Selat District, especially by TFL, who is tasked directly in the front guard facing the community. The dilemma in carrying out tasks when a pandemic has broken down thoughts, focus and plans that have arranged. Circumstances with constraints of various things, it is felt necessary to conduct a study in rapid duration as a preventive measure from TFL or multiple parties to address the situation of the COVID-19 pandemic force majeure in the field.

Discussion on this topic will lead to two important things, first the distribution mechanism that will analyze the identification of field constraints and second, preventive measures in dealing with conditions related to the distribution of aid amid the COVID-19 pandemic. Both reviews will explain together the solution separately, and the various actions are taken always go hand in hand. Delivery of assistance during the pandemic to handle activities related to the community of Muncan Village, formulating strategies for various meetings that must be held in connection with BSPS, following applicable regulations. So that the various actions are taken or carried out by the BSPS team in the field and the local village community, did not violate the rules that have been set and also did not suffer moral or material losses. In addition to the things mentioned earlier, this review also aims to expand domestic and international information that the Indonesian government is always trying to deal with pandemic conditions and continues to implement a home improvement program through BSPS PUPR for low-income people. The results of this study are expected to be considered the implementation of procedures related to approaches in the community so that the process runs effectively and efficiently. This research is also expected to have a positive impact on BSPS in the future as well as beneficiary communities, especially the handling of aid distribution processes in force mejaure situations such as the COVID-19 pandemic. 


\section{LITERATURE REVIEW AND METHOD}

\section{Criteria for Decent House and Inadequate Houses}

In terms of criteria, there are two types, namely feasible and uninhabitable. The eligibility references in this review refer to the generally accepted basic rules, which stated in the Law of the Republic of Indonesia Number 1 of 2011 which states that a house is a building that functions as a habitable residence, a means of fostering family, a reflection of the dignity its inhabitants (Nasional, 2011). Whereas WHO discusses that the house is a physical structure or building shelter, the environment is useful for physical and spiritual and social conditions both the health of families and individuals (Lingkungan, 2001).

\section{Criteria for Livable Housing}

(according to KEPMEN KIMPRASWIL No, 403/KPTS/M/2020 \& PERMENPERA No. 22/PERMEN/M/2008)

Livable Houses are houses that meet the building safety requirements and the minimum adequacy of the building area and the health of the occupants.

To create a livable house, consider the following:

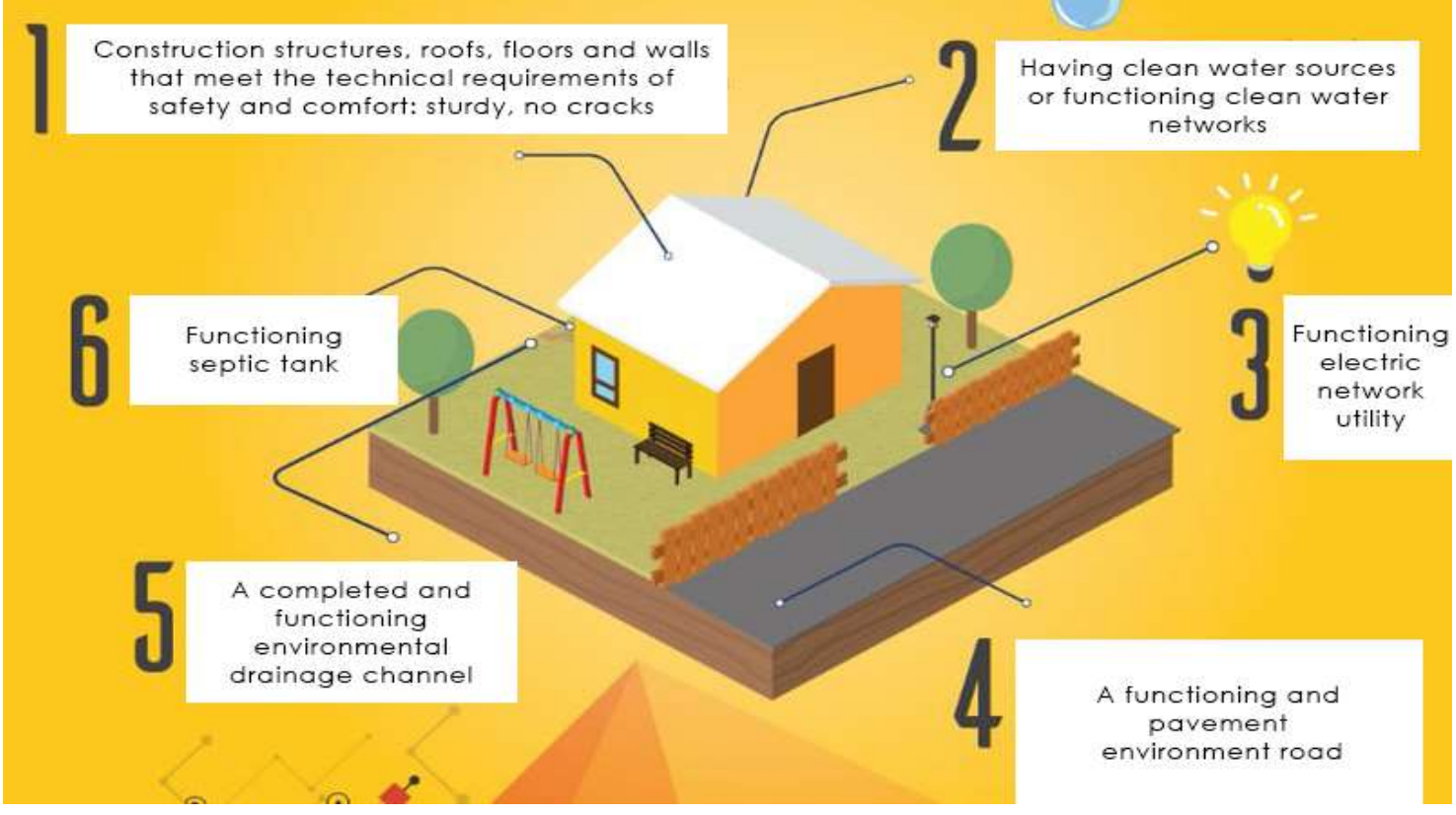

Figure 1. Infographics of livable homes

[Source: PUPR] 
Based on the discourse about the house, it assumed that the house is an essential part of human life, not just a physical shelter but also a value of comfort and health and safety for its inhabitants. The same thing is also related to Law of the Republic of Indonesia No. 4 of 1992 concerning housing and settlements, which says that housing is a group of houses that functions as a residential or residential environment that equipped with environmental infrastructure and facilities (Pusat, 1992).

A different discourse says that house as protection of various natural events, or residential homes and shelter from the influence of ambient conditions such as heat or rain and as a place to rest in meeting the needs of daily life (Suharmadi, 1985). While other technical and non-technical discourses explained that the house is not suitable for habitation, namely shelter with limited space or does not support function, unhealthy water sources, access to clean water is very limited, and do not have facilities for bathing, washing, toilet (Juniartini, 2019). Another thing is the building does not use permanent materials, ventilation is lacking or has no function at all, the humid state of the room with the floor from the ground, and the position of the building which coincide (Juniartini, 2019). Based on the discourse, assessment of the aspects of management and issues of comfort that not met, it will have an impact on various criteria of concern in development as an appropriate and improper selection parameter for a building.

Referring to livable parameters from the recommendation of the Directorate General of Public Housing Financing at the Ministry of Public Works and Housing, the recommended requirement is a minimum building area of 9 $\mathrm{m} 2 /$ person and also related to the health level of its occupants. Meanwhile, from the physical side of the building, it includes structural components, floors, roofs, walls, and supported by sanitation, lighting, air circulation related ventilation, and availability of clean water supply (Juniartini, 2019). General description of criteria for livable homes can explain in the infographic in figure 1. 


\section{Constraints and Solutions in the Previous BSPS Implementation (Case Study of Tusan Village)}

In the initial verification process or before the implementation period, TFL as a field officer dealing directly with the community needs to study the situation in various coordination areas throughout Bali. Research procedures and a focus also conducted in one area, namely the Muncan Village, Selat District, Karangasem Regency. This is related to the study data collected as a sample of BSPS implementation from the majority of the data covering Muncan Village in the case study. But similar to the analysis, as a comparison, research material refers to the BSPS activities that have published. The previous implementation of BSPS was in the area of Tusan Village, Banjarangkan Regency, Klungkung Regency, in 2019 so that the situation that occurred in the implementation became a parameter of experience for the implementation of the BSPS 2020 on social and cultural conditions in the Muncan Village area.

Obstacles and solutions for finding solutions in the previous study by Juniartini (Juniartini, 2019) on the BSPS program with the territory of Tusan Village are namely:

1) Social constraints: the relationship between individuals in the village environment that has led to reluctance in collaborative work outside the region even though it needed in the development process.

Solution: motivate the self-supporting workforce and collaborate according to expertise.

2) Educational constraints: the development process based on experience and not through formal education so that the egoism of the experience is not following applicable rules and regulations.

Solution: always provide assistance and balance so that the process runs according to the proposal and budget formal requirements.

3) Situation constraints: process scheduling constraints that are affected by the situation of traditional life and local religious activities which have an impact on the delay in the development process.

Solution: anticipated by utilizing the maximum free time by providing work management education in mutual cooperation. 
In the review, the previous situation experience, namely in Tusan Village, was an important component and consideration in responding to the symptom of the situation in a different region, namely in Muncan Village. However, differences in the case study area do not rule out the emergence of obstacles other than those that have occurred in previous experience, because habits, traditional life, and so on, can affect the elements of each obstacle, along with the necessary solutions. Benchmarking references are important factors leading to conclusions in the discussion and supporting commentaries on the phenomena that occur (Setiawan, 2020).

\section{COVID-19 Pandemic}

Various technical or non-technical field constraints have become even more complicated with the existence of the COVID-19 pandemic situation and changing the job to be very different from previous experience concerning BSPS. Field teams such as TFL must take action to re-arrange their fieldwork plans and must consider the rules regarding the health and handling of a pandemic. Pandemic forced the government and various parties to take action by limiting the scope of public activity. It undoubtedly aimed at encouraging health procedures and reducing the spread of pandemic as much as possible.

In the field team position, the first preventive measure was to get to know the pandemic from COVID-19 by digging up as much information as possible. COVID-19 is a virus commonly called the coronavirus with the receipt name SARS-CoV-2, now causing a global pandemic and has spread to more than 190 countries in the world including Indonesia (Putri, 2020). Then the global catastrophic outbreaks led to various anticipatory actions to suppress the distribution and transmission charts that have been massive. Steps in the attempt to reduce transmission such as social distancing, isolation and quarantine, lockdown, flattening the curve, to the supervision and monitoring of patients (Nadhira, 2020). Through the Ministry of Health, Coronavirus is a large family of viruses that cause diseases ranging from mild to severe symptoms. There are at least two types of coronaviruses that are known to create conditions that can cause severe symptoms such as Middle East Respiratory Syndrome (MERS) and Severe Acute Respiratory Syndrome (SARS). 
Coronavirus Disease 2019 (COVID-19) is a new type of disease that has never been identified before in humans. The virus that causes COVID-19 is called Sars-CoV-2. Coronavirus is a zoonosis (transmitted between animals and humans) (Isbaniah et al., 2020).

\section{Distribution of BSPS in the Procedure and Mechanism}

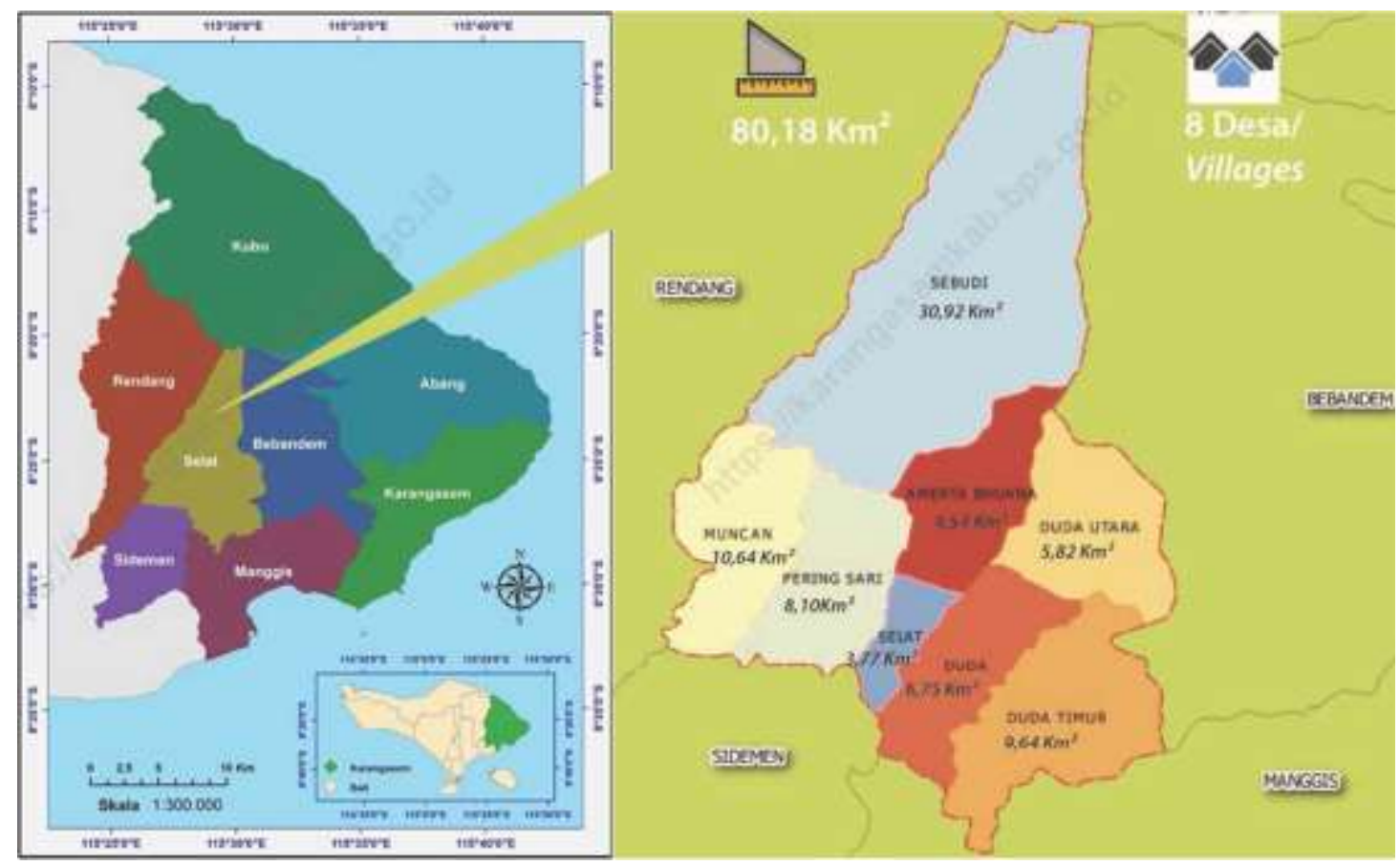

Figure 2. Map of Muncan Village, Selat District, Karangasem Regency.

[Source: BPS]

In the action of data collection, through field data comparison based on procedures and previous study data related to BSPS. The data that has been collected is then sorted on its criteria and has a relation to the constraints and solutions without violating the applicable rules and procedures. Data collection used is purposive sampling, which determines informants with certain considerations or criteria (Sugiyono, 2009). In general criteria, the data taken based on communities domiciled in the Muncan Village area of the Selat Subdistrict by occupying the only houses in a condition not livable and earning below the district minimum wage. Based on the 2019 data reference, it shows that the figure is Rp. 2,355,054,- (Ermalia, 2019). Another criterion is that the beneficiary has never received housing program assistance and is able to be 
self-sufficient and coordinated in a group of beneficiaries (Kelompok Penerima Bantuan/KPB) with mutual responsibility.

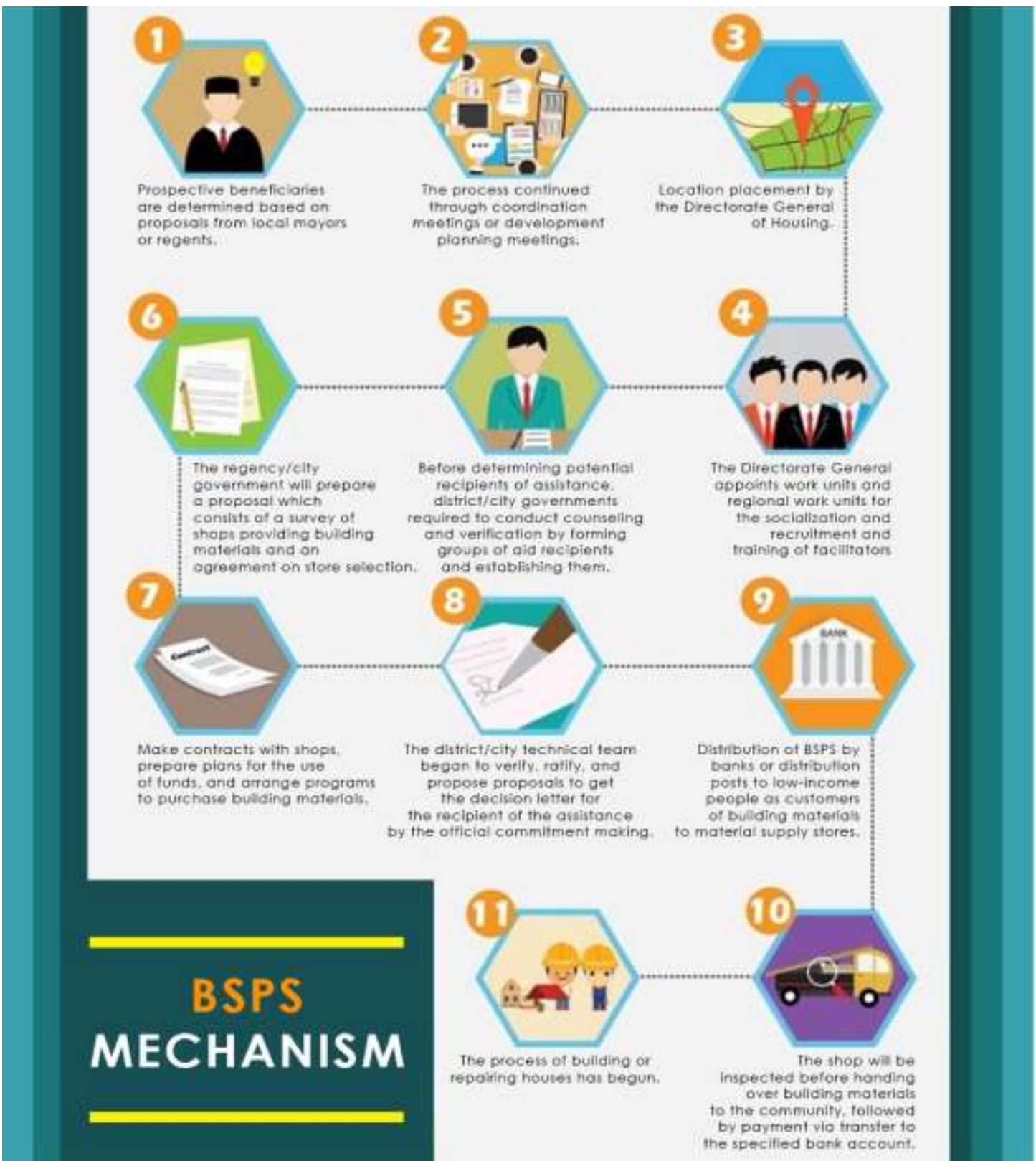

Figure 3. Infographics about the BSPS mechanism

[Source: SNVT]

Due to data from the Central Statistics Agency of Karangasem Regency, Muncan Village in official administration and as part of the Strait District has a population density of 8,327 people in 2019 (Karangasem, 2019). In Muncan Village, there are 13 hamlets, namely Kaja, Manik, Pendem, Gunung Biau, Meranggi, Muncan, Kawan, Susut, Gede, Pemuhunan, Pakudansih, Benekasa, 
and Yangapi (Muncan, 2015). Muncan village as one of the villages receiving BSPS 2020 assistance (for 100 housing units/beneficiaries) from many villages in Bali and at the same time as the focus of the region in the review of the study (figure 2).

The following data were obtained based on PUPR socialization through Specific Non-Vertical Work Unit (Satuan Kerja Non Verikal Tertentu/SNVT) in the briefing to the 2019 field technical team related to BSPS. The data is determined based on the mechanism prevailing at BSPS, the procedural travel process in the area of Muncan Village, Selat District, Karangasem Regency, described as follows (figure 3 ):

1) $C P B$ is determined based on the district head's recommendation through village level recommendations.

2) The decision followed up with a development planning coordination meeting.

3) Determination of BSPS location by the Directorate General of Public Housing.

4) Appointment of Regional Work Units (Satuan Kerja Perangkat Daerah/SKPD) tasked with conducting socialization, recruitment and equipping facilitators.

5) District and city governments are required to attend counselling and verification by assigning TFL, after which they form a KPB and determine it.

6) The district government prepares proposals, surveys suppliers of materials and agreements with these parties.

7) make contracts with material providers, arrange the use of funds and plan to purchase materials.

8) District technical team verifies, validates, proposes decision letters by Commitment Making Officials (Pejabat Pembuat Komitmen/PPK).

9) Disbursement of funds by the bank or by channelling to Low-Income Communities.

10) Transactions made via transfers between bank accounts that have determined.

11) The development process starts according to the requirements. 


\section{RESULTS AND DISCUSSION}

In the introduction, it is explained that the review would refer to two crucial issues. It was assessed based on the field conditions in the Muncan Village area, namely the initial process of implementing BSPS and implementing the program during a pandemic situation. The initial process is related to the identification of problems that have arisen in Tusan Village by referring to studies that have been done before, compared to the data obtained in the initial process of program implementation. The implementation of the program during a pandemic refers to the exposure of the implementation initiative by following the health protocol and other rules. The limitations of the review in the discussion, limited to data collection up to the fourth month, namely April 2020 due to limited field activities, publication, data analysis, and policy recommendations during the pandemic. In general, the limitations of study data are due to unfavourable conditions during the pandemic. Still, data can be collected collectively and maximally by continuing to approach and communicate in the field. Clustering several works processes greatly help all existing limitations so that the effectiveness of the procedure stages continues to run efficiently following research planning. The work cluster in question, one example is the scheduling of direct communication (in mentoring activities) with proper duration planning so that no crowd occurs during the process and does not violate the recommended protocol. That is why the collection of data that can be analyzed is limited to activity data from November 2019 to April 2020 and is described based on field facts.

\section{State of Muncan Village Area (T-1 Implementation)}

$\mathrm{T}-1$ implementation is a process that refers to data collection through a survey process leading to field verification of CPB conducted by TFL as a verifier before entering the year of realization in 2020. The implementation period includes the preparation of administrative proposals, which have a duration of approximately one month, from November to mid-December 2019. The process mechanism refers to the activities of points 1 through 6 in the BSPS mechanism stage. Execution of tasks based on SNVT Decree No. 111 / KPTS / SNVT-PnP.BALI / 2020 which applies to the whole of Bali, but the 
subject of the discussion is the assignment of TFL in Muncan Village, subregion of BSPS, Karangasem Regency.

Table 1. Identifikasi sosio-kultural Desa Muncan [Source: Authors data analysis]

\begin{tabular}{|c|c|c|}
\hline Social Conditions & Educational Conditions & Situation Conditions \\
\hline $\begin{array}{l}\text { There was an action of disputing } \\
\text { political views by some } \\
\text { community groups caused by the } \\
\text { village head election agenda. }\end{array}$ & $\begin{array}{l}\text { The general understanding of the } \\
\text { community that the BSPS } \\
\text { program is a form of cash } \\
\text { distribution and is handed over to } \\
\text { beneficiaries. }\end{array}$ & $\begin{array}{l}\text { Access to facilities and } \\
\text { infrastructure in some } \\
\text { circumstances is still very } \\
\text { lacking in field conditions, so it } \\
\text { affects the timing of } \\
\text { implementation (for example } \\
\text { some CPB locations must be } \\
\text { travelled on foot on a trail and } \\
\text { requires a matter of hours to } \\
\text { reach one location). }\end{array}$ \\
\hline $\begin{array}{l}\text { There is a dispute over family } \\
\text { members in one house, so the } \\
\text { process of socialization and } \\
\text { mentoring becomes more } \\
\text { difficult. }\end{array}$ & $\begin{array}{l}\text { Lack of awareness of potential } \\
\text { recipients of assistance in } \\
\text { following and complying with the } \\
\text { actual process, even though it } \\
\text { must be met and carried out in } \\
\text { every implementation process. }\end{array}$ & $\begin{array}{l}\text { Some places have quite heavy } \\
\text { field conditions by steep inclines } \\
\text { and steep slopes and rough } \\
\text { rocky surfaces when looking for } \\
\text { CPB locations that are not close } \\
\text { together. Constraints will be } \\
\text { more severe when the rainy } \\
\text { season or access the location in } \\
\text { wet conditions. }\end{array}$ \\
\hline $\begin{array}{l}\text { The status of the community in } \\
\text { individual administrative cases, } \\
\text { namely the condition of the truna } \\
\text { tua / single age elderly, so that } \\
\text { they do not have the opportunity } \\
\text { to be proposed to be recipients } \\
\text { of assistance even though it is } \\
\text { very feasible. }\end{array}$ & $\begin{array}{l}\text { Indications of intervention by } \\
\text { several elements in the mode of } \\
\text { having a relationship with officials } \\
\text { to distort various matters related } \\
\text { to procedures, such as } \\
\text { administration and bureaucracy } \\
\text { which are officially listed and } \\
\text { explained in the standard } \\
\text { operational procedures of BSPS. }\end{array}$ & \\
\hline $\begin{array}{l}\text { Lack of awareness to take care } \\
\text { of self-identity administratively, } \\
\text { especially in the elderly. }\end{array}$ & $\begin{array}{l}\text { The limited knowledge of building } \\
\text { techniques is based on } \\
\text { experience so that it raises } \\
\text { unilateral actions without } \\
\text { coordination by the CPB as if it } \\
\text { had mastered the procedure. }\end{array}$ & \\
\hline
\end{tabular}

The review, in general, still uses the basis of three conditional analyzes, namely social conditions, educational conditions, and situation conditions based on the approach to the socio-cultural situation at the time. If described, the case raises a variety of new obstacles outside of the previous constraints on BSPS 2019 in Tusan Klungkung Village, especially notes from field survey data in the verification process of each proposed location. Some obstacles that arise in the verification process outside of the standard operating procedures BSPS 2019 (in the implementation of T-1 verification) and are described in socio-cultural 
identification table 1. Data obtained from various sources such as regional leaders, village heads, society, news, and so on that can be held accountable for its validity. Specifically, data from information relating to the local political atmosphere again excavated from electronic media reports other than interviews, as well as reporting on disputes during the village head election agenda (SUYATRA, n.d.).

\section{Percentage of Self-Supporting from Beneficiaries}

In Muncan Village, according to data collected during the duration of the study and initial mentoring, it can be seen the enthusiasm of beneficiaries. In the data can be measured the percentage of self-support recipients of their expectations to have a decent home. The self-support is not in the form of raw funds, but the material that has been owned by each beneficiary that will support stimulus assistance from the government. Next can see in the table with a graph of the percentage of PB self-supporting values and their averages.

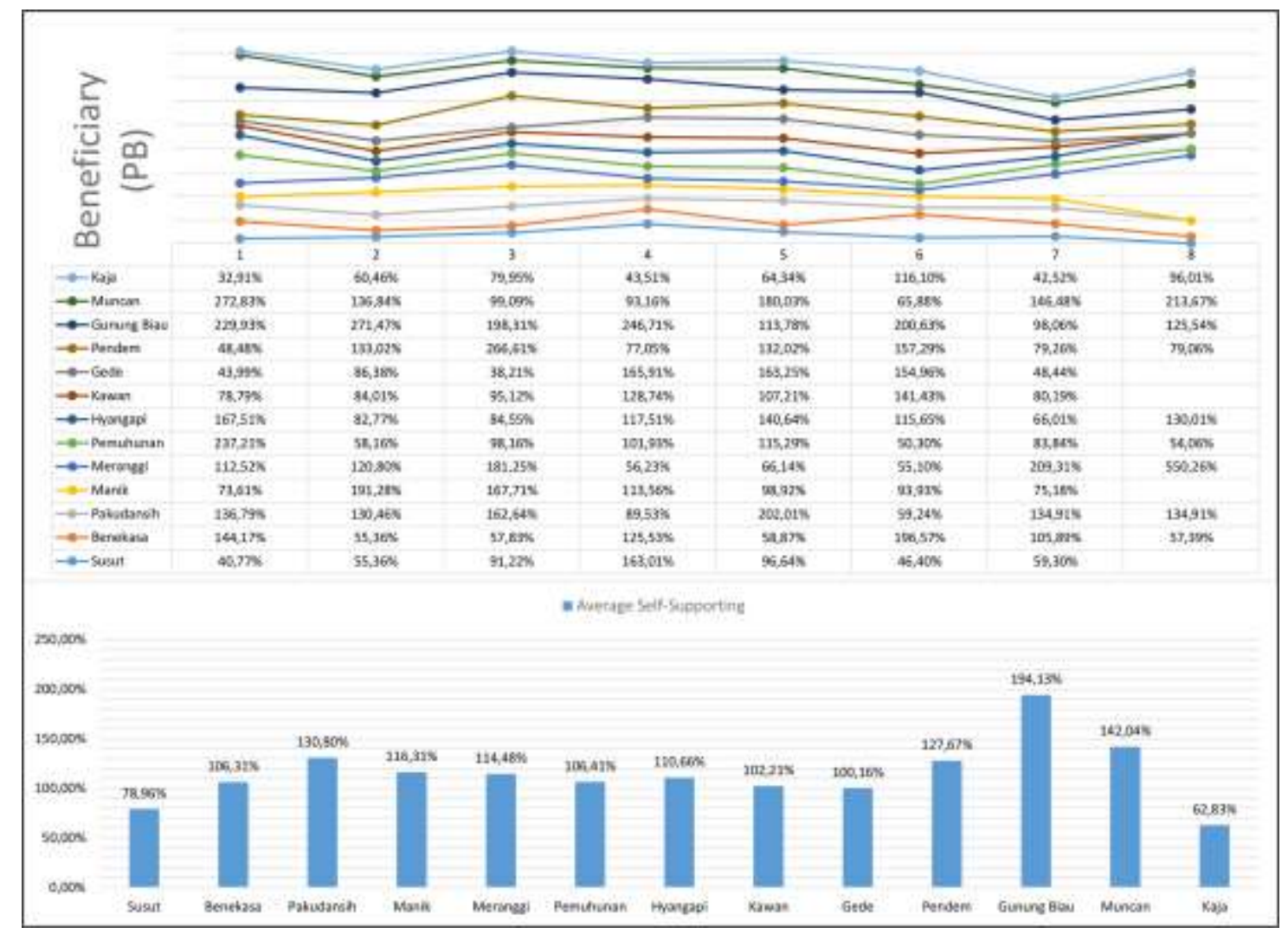

Figure 4. Percentage of the value of self-supporting recipients in each village [Source: TFL data] 


\section{Pandemic Anticipation in Task (Continued Process)}

The existence of the COVID-19 outbreak since the beginning of 2020 has become a severe disaster globally and forced the world community to be more vigilant in every situation and to obey the government's recommendations regarding health protocols in a pandemic. The problems of the BSPS program during the COVID-19 pandemic make activities in the implementation of the process a very significant obstacle because, in the procedure, interaction with the community especially beneficiaries needs to carried out directly. Direct meeting with $\mathrm{PB}$ and $\mathrm{CDE}$, in addition to assisting in designing the house and making a budget plan that is following the provisions of the BSPS. Procedures in mentoring and activities in other process ranges require intense communication and coordination to be part of the main task of TFL as the front guard face to face with PB. The assistance aims to monitor and ensure the process in the field, run well and review the stages of each process according to the working mechanism so as not to break out of the rules that have been set. The outbreak of the COVID-19 outbreak from the beginning of the year was very unpredictable, adding to the long list of obstacles in the field due to the need for additional planning in anticipating the spread of COVID-19 outside the planned process.

Based on a circular in anticipating field conditions in the BSPS implementation process, taking a reference the legal basis issued by the Ministry of Public Works and Public Housing (PUPR), the Directorate General of Housing, the Directorate of Self-Helped Houses, among others (Direktorat Jenderal Perumahan, 2020):

1) Indonesian Republic Constitution article 1 of 2011 about Housing and residential area

2) The decree of President article 11 of 2020 about the establishment of citizen emergency state over the Corona Virus Disease (COVID-19)

3) The decree of Minister of Administrative and Bureaucratic Reform article 35 of 2012 about the Guidance of Government Administration's Standard Operational Procedure establishment 
4) The decree of the Minister of Public Work and Housing of Indonesia article 03/PRT/M/2019 about organization and job description in the Ministry of Public Work and Housing of Indonesia

5) The decree of Minister of Public Work and Housing of Indonesia article 07/PRT/M/2018 about the Stimulant Program of Self-subsistent Housing

6) The decree of the Minister of Health article 9 of 2020 about the social distancing guidance and the Accelerated Preventive Action onto Corona Virus Disease (COVID-19)

7) The instruction of the Minister of Public Work and Housing of Indonesia Article 02/IN/M/2020 about the Accelerative Prevention onto Corona Virus Disease (COVID-19) in the Construction Services establishment

8) A Circular of Director General of Housing article 3 of 2020 about the Operating Procedure of Construction Working on Directorate Technical in Directorate General of Housing's environment during the Pandemic of COVID-19

9) The Prevention Protocol on COVID-19 in Construction Project of Construction Directorate General

The legal basis described is related to implementing qualifications, health protocols, work procedures, equipment, warnings, recording and data collection, as well as technical guidelines for implementing BSPS during the COVID-19 pandemic period, which must be followed primarily by the field team and all levels of the community involved. The legal basis and work protocol issued by related parties are as a form of preventive action during the pandemic period and as a basis for information to educate the public about the anticipation of COVID-19. BSPS assistance and education about COVID-19 go hand in hand at each opportunity face-to-face with the people of Muncan Village by continuing to put forward the proper protocol.

There are three parts of action (three actions) based on field facts, namely the first act of carrying out tasks in the middle of a pandemic, the frontline field team (two TFL) for Muncan Village served based on a work contract marked by the Decree of the Head of SNVT. The letter also became the basis of legal force for all activities carried out in Muncan Village relating to 
BSPS and as an introduction to identification by the COVID-19 Task Force in each village area traversed.

The second action is community obedience, especially beneficiaries in undergoing all the procedures and obligations in the BSPS, including following the health protocol in assistance. The third action is in the middle of the other actions, called the stimulus action (initiative zone) or in different meanings as a supporting action to increase the security of both parties when facing a pandemic situation in their duties and obligations.

The third action was carried out on a personal initiative and carried out at their own expense without intervention, for example from the third act of donating 100 maskers to 100 beneficiaries distributed through the Muncan Village Head and foodstuffs for the elderly and orphans to 20 households (as affected) channelled through the COVID-19 task force in Muncan Village. The third action initiative was carried out by Ni Luh Putu Juniartini as the Field Facilitator Team (TFL) officer as a form of TFL closeness to the people of Muncan Village and a stimulus to increase community initiatives in implementing BSPS programs and health protocols well. Next is the action plan that has been reviewed and presented in table 2, and the action plan described in more detail.

Table 2. Three actions in the middle of a pandemic [Source: Authors data analysis]

First Action (TFL)

Follow and run the BSPS procedure by the stages that have determined:

- BSPS mechanism

- Circular of BSPS implementation

- SNVT Decree

- BSPS regulatory, warning and risk mechanism violations

\section{Third Action} (Initiative Zone)

A donation of 100 maskers for 100 beneficiaries distributed through Muncan Village Head and 60 maskers for kids (by TFL Ni Luh Putu Juniartini).

Aimed at receiving aid to prioritize security for health during assistance in the field

\section{Second Action (PB)}

Follow and obey the BSPS procedure in accordance with the stages that have been determined or recommended during mentoring:

- BSPS mechanism

- Obligations as PB.

- Contracts and statements are self-supporting and follow the rules in the BSPS

Food donations for the elderly and orphans to 20 families affected by the pandemic at their own expense channelled through the COVID-19 Task Force (by

TFL Ni Luh Putu Juniartini)

As a form of the closeness of TFL
Running health protocols in using self-protection tools:

- Mouth mask 


\begin{tabular}{|c|c|c|}
\hline & $\begin{array}{l}\text { and PB assistance the people of } \\
\text { Muncan Village }\end{array}$ & \\
\hline $\begin{array}{l}\text { Running health protocols in } \\
\text { interaction: } \\
\text { - Sneezing and coughing ethics } \\
\text { - Wash hands with soap } \\
\text { - Always wear a mask and } \\
\text { glove } \\
\text { - Maintain physical distance } \\
\text { - Hand sanitizer for PB. } \\
\text { - Disinfectants to sterilize } \\
\text { equipment used repeatedly } \\
\text { by PB, such as ballpoints, } \\
\text { tables or other equipment } \\
\text { - Schedule, provide space for } \\
\text { each meeting with PB and the } \\
\text { territory to avoid crowds }\end{array}$ & $\begin{array}{l}\text { Providing health protocol } \\
\text { education to beneficiaries by } \\
\text { inserting material in each } \\
\text { mentoring and outreach. } \\
\text { (by TFL Ni Luh Putu Juniartini) } \\
\text { The aim is that beneficiaries at } \\
\text { the time of assistance have } \\
\text { information and knowledge } \\
\text { related to health protocols and } \\
\text { additional information about } \\
\text { COVID-19 }\end{array}$ & $\begin{array}{l}\text { Running health protocols in } \\
\text { interaction: } \\
\text { - Sneezing and coughing } \\
\text { ethics } \\
\text { - } \quad \text { Always use a mask } \\
\text { - Maintain physical distance } \\
\text { and arrange position in the } \\
\text { assistance room } \\
\text { - Willing to use a hand } \\
\text { sanitiser, or } \\
\text { - Willing to spray disinfectant } \\
\text { on hands interacting with } \\
\text { TFL } \\
\text { - Washing hands before and } \\
\text { after interacting }\end{array}$ \\
\hline $\begin{array}{l}\text { Running health protocol after } \\
\text { mentoring activities: } \\
\text { - Wash your hands with soap } \\
\text { - Spray disinfectant on a } \\
\text { device that used repeatedly } \\
\text { - Disposing of the disposable } \\
\text { glove } \\
\text { - Wash clothes and masks (or } \\
\text { throw them away if } \\
\text { disposable) used in activities } \\
\text { - Cleanse the body with a } \\
\text { shower } \\
\text { - Avoid using public } \\
\text { transportation }\end{array}$ & $\begin{array}{l}\text { Every field meeting or every } \\
\text { interaction in mentoring, always } \\
\text { providing and maintaining } \\
\text { availability: } \\
\text { - Hand sanitizer } \\
\text { - Disinfectan sprayer liquid } \\
\text { - Disposable glove } \\
\text { - Disposable or fabric masker } \\
\text { (by TFL Ni Luh Putu Juniartini) } \\
\text { Aim to implement a health } \\
\text { protocol for each interaction with } \\
\text { the community. }\end{array}$ & $\begin{array}{l}\text { Running health protocol after } \\
\text { mentoring activities: } \\
\text { - Wash your hands with soap } \\
\text { - Wash clothes and maskers } \\
\text { (or throw them away if } \\
\text { disposable) used in activities } \\
\text { - Cleanse the body with a } \\
\text { shower after activity }\end{array}$ \\
\hline
\end{tabular}

Next in figure 5 is the Personal Protection Tool (APD) infographic that is used by the Field Facilitator Team (TFL) in following the self-provided health protocol. Infographics are designed based on considerations of simplification in the execution of ideas or ideas as outlined in the pictorial media (Setiawan \& Jayanegara, 2019). The presence of infographic intermediaries also provides information that is more communicative, simple, and easy to understand because it presented with visual illustration information. In addition, there are also pictures during the meeting activities, assistance, and the situation of beneficiary houses in figure 6 and figure 7 . Mechanically, direct meetings are held by dividing meeting participants into consideration of room capacity and maintaining a physical distance so that one meeting theme is repeated repeatedly in frequency and certain duration to avoid crowds and to run other rules relating to health protocols. When mentoring done the same thing, namely maintaining physical distance and other protocols, which carried out by spraying disinfectant on equipment that used repeatedly, calls for hand washing or using 
a hand sanitizer, and other health protocols as self-protection. All equipment is provided at own expense by TFL (based on initiative) although in written rules that the availability of personal protective equipment is facilitated by the PUPR.

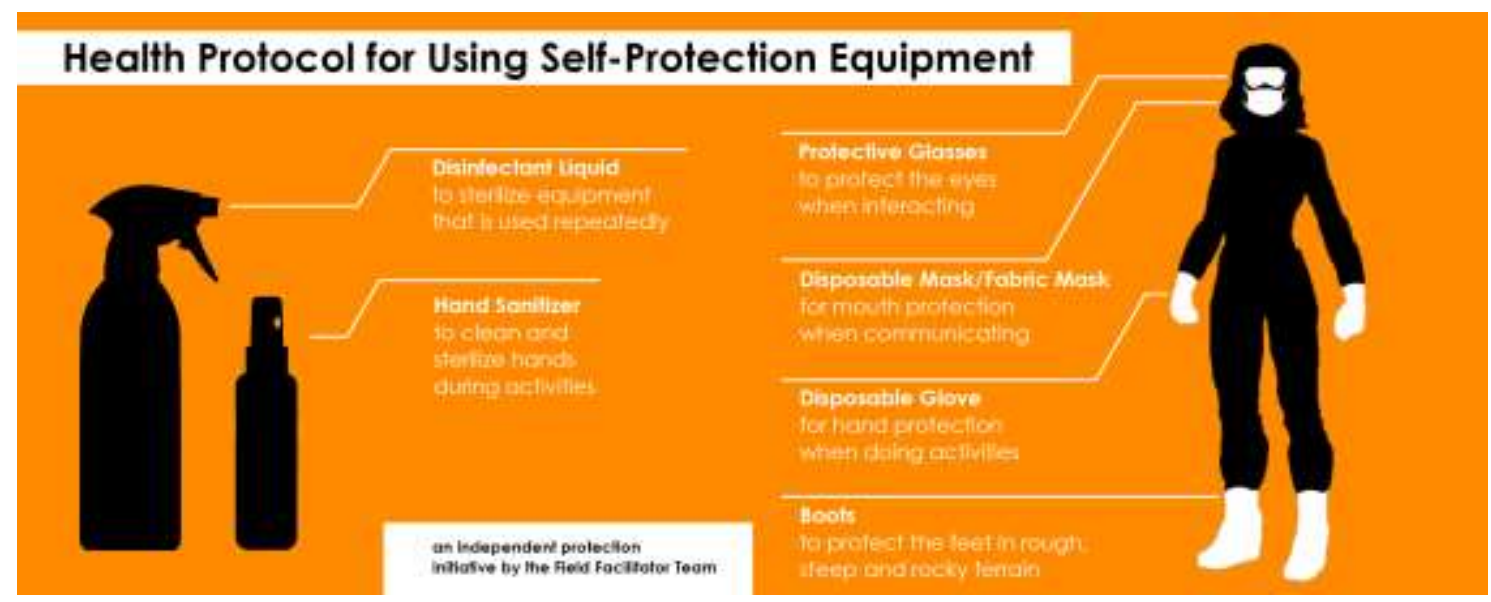

Figure 5. Independent protection initiative by the Field Facilitator Staff [Source: authors]

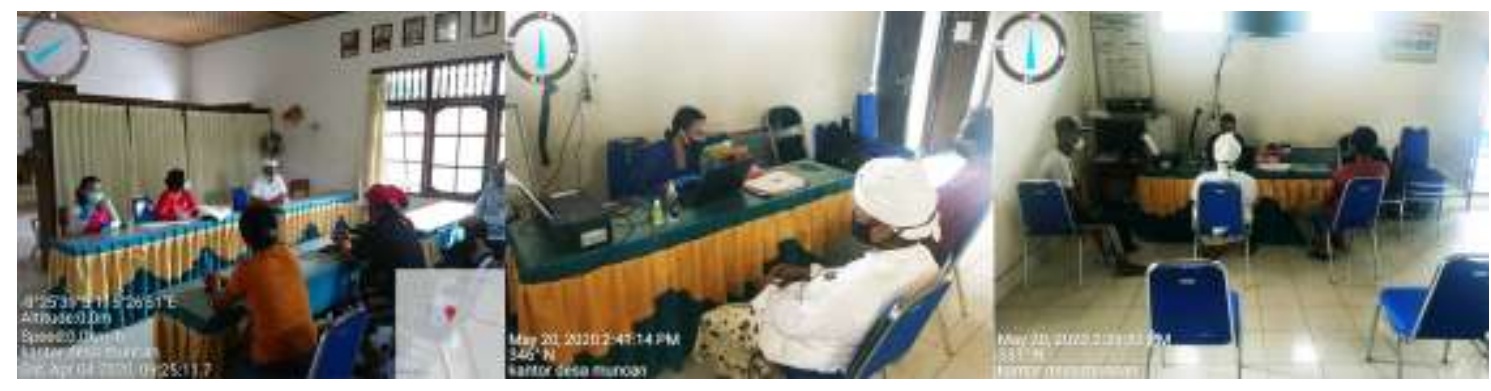

Figure 6. Meetings and mentoring by TFL, village heads and beneficiaries by implementing health protocols [Source: authors]

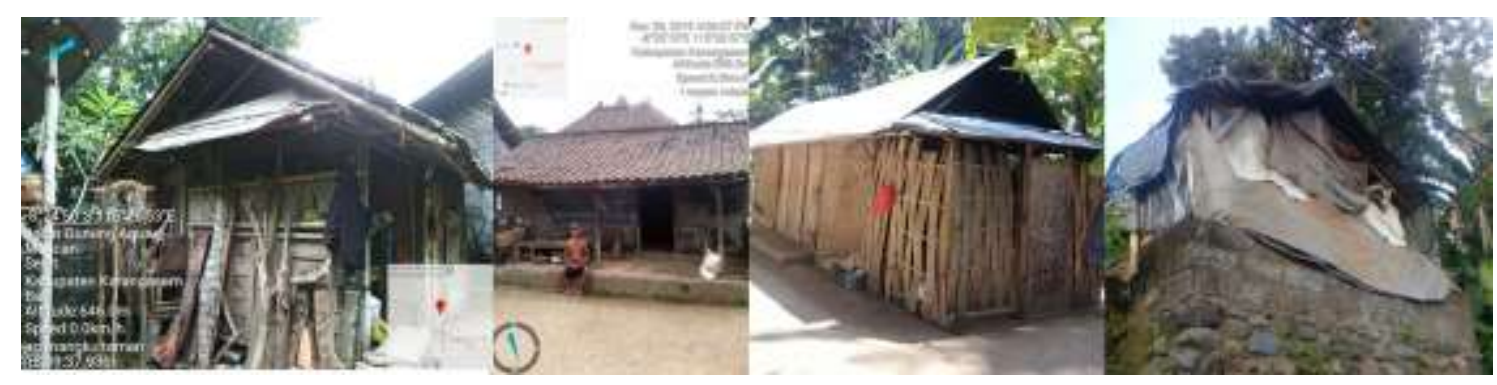

Figure 7. Documentation of the situation of beneficiary housing [Source: authors] 


\section{The Role of Village and Traditional Village Synergy in the Acceleration of Handling COVID-19}

The COVID-19 pandemic did indeed have a considerable impact not only on health issues but also on various other lines such as its impact on the economy and changes in daily life. The government at the village level is also absolutely required to carry out its role as well as preventive measures through various policies to accelerate the handling of a pandemic. The thing is that in villages in Bali, there are two systems of government. Still, they have different scopes in their territories, namely the official village government system (desa dinas) and the conventional village government system (desa adat). Until now, formal governance (dinas) as a role in the administrative management of state administration at the village and traditional village levels (adat) plays a role in the management of local regular socio-cultural life. As mentioned, the official villages and customary villages have their respective roles with different management but still within the same scope (Noak, 2016). The existence of government duality at the village level does have different regions and domains, but in general, its existence still recognized by the community.

In connection with the existence of a pandemic although no cases have yet been found, Dinas Muncan Village as an element of the local government plays a role in managing various matters related to policies from the central government by empowering village funds (in two government structures) allocated for handling pandemics accompanied by the military (TNI/Babinsa) and police (POLRI/Babinkantibmas). In the traditional village structure, the role carried out is the establishment of the COVID-19 task force through the decision of the adat meeting (perarem) based on the appeal of the provincial government of Bali. The synergy in general works well, although sometimes it creates controversial overlapping policies in the duality of village-level government. From the perspective of TFL, the pandemic situation makes a difference in the communication space, especially various matters related to BSPS. However, this situation can be handled because of early communication and socialisation from the BSPS activity schedule had carried out before the COVID-19 pandemic occurred, so there were not too many significant problems related to the arrival of BSPS officers. Some things that are needed by TFL while on duty 
in Muncan Village are identity completeness and administration of assignments related to BSPS activities as notes or data collection for customary and official officers according to policy procedures in Muncan Village, considering TFL officers come from outside the Muncan Village area.

Things that need to be appreciated apart from COVID-19 handling measures from adat and dinas, the readiness of regional leaders is also constructive in the ongoing process especially regarding the data of beneficiaries and motivating each group of beneficiaries. In addition to the local leaders understanding the existence or condition of their respective regions, it is also obligatory to oversee the ongoing process and ensure that the procedural rules run well and clean. Regional Chairpersons from 13 territories in Muncan Village, $65 \%$ of local leaders are very dedicated as village service facilitators, especially in the BSPS process. Based on field performance during the BSPS (until April 2020), the performance of regional leaders can be measured based on the performance of the excellent category of 1 peoples, a useful grade of 4 peoples, and good enough of 9 peoples.

\section{Analysis of BSPS Distribution in Muncan Village (until April 2020)}

Table 3 is the overall results of findings and actions that can be taken in response to the situation in the Muncan Village area. In implementing BSPS, stick to the rules that have been set and refer to the facts of the field, so that the next mechanism can work well with preventive action. To reduce the risk of obstacles in the field, there must be a balance of awareness among various parties, especially when the distribution of aid during a COVID-19 pandemic.

Table 3. Analysis of identification and solutions

[Source: Authors data analysis]

\begin{tabular}{|c|c|c|}
\hline Object & Identification/Indication & Solution/Preventive Action \\
\hline Social & $\begin{array}{l}\text { - Political perspective disputes } \\
\text { - Disputes between family members } \\
\text { - Special cases } \\
\text { - Population administration }\end{array}$ & $\begin{array}{l}\text { - Mediation with village officials } \\
\text { - Keep running the BSPS procedure } \\
\text { - Report findings to SNVT } \\
\text { - Empowerment of Regional Heads } \\
\text { - Strengthening coordination of } \\
\text { - Services and teams } \\
\text { - Support of TNI and POLRI }\end{array}$ \\
\hline
\end{tabular}




\begin{tabular}{|c|c|c|}
\hline Education & $\begin{array}{l}\text { - Understanding of assistance } \\
\text { - Awareness follows the rules } \\
\text { - Interventions of certain elements } \\
\text { - Limited technical knowledge }\end{array}$ & $\begin{array}{l}\text { - Socialization of the BSPS mechanism } \\
\text { - Motivation and risk of violation } \\
\text { - Cannot be intervened } \\
\text { - Evidence and factual data } \\
\text { - Understanding when mentoring }\end{array}$ \\
\hline Situation & $\begin{array}{l}\text { - Inadequate infrastructure } \\
\text { - Field with heavy terrain }\end{array}$ & $\begin{array}{l}\text { - Mental readiness of the field team } \\
\text { - Readiness of physical equipment } \\
\text { - Coordinate the head of beneficiaries }\end{array}$ \\
\hline $\begin{array}{l}\text { The COVID-19 } \\
\text { pandemic period } \\
\text { (Facilitator team) }\end{array}$ & $\begin{array}{l}\text { - PUPR circular } \\
\text { - Health protocol } \\
\text { - BSPS mechanism procedures }\end{array}$ & $\begin{array}{l}\text { - Understand and apply the rules } \\
\text { - Personal protective equipment by } \\
\text { SNVT } \\
\text { - Preparation of self-protection } \\
\text { - Prioritize the protocol } \\
\text { - TFL initiative actions }\end{array}$ \\
\hline $\begin{array}{l}\text { The COVID-19 } \\
\text { pandemic period } \\
\text { (Beneficiary) }\end{array}$ & $\begin{array}{l}\text { - Health protocol } \\
\text { - BSPS mechanism procedures } \\
\text { - Situation and condition of the village }\end{array}$ & $\begin{array}{l}\text { - Self motivation follows the protocol } \\
\text { - Obligation to follow the mechanism } \\
\text { - Scheduling live meetings } \\
\text { - Control the duration } \\
\text { - Follow TFL advice }\end{array}$ \\
\hline
\end{tabular}

\section{CONCLUSION}

It can be concluded several things that are considered in the next process. These conclusions will be able to provide important input in various situations and conditions in each area of aid distribution, especially in the condition of force majeure. The conclusion is as follows: (1) The field team always adheres to the rules, procedures, protocols and mechanisms that apply so that it has a strong basis in argumentation (technical or non-technical) or intervention in the field. (2) Provide the community with as much detail as possible about the rights and obligations of beneficiaries and motivate the process of resolving obligations with the assistance of the field team. (3) The field team must understand the preventive actions and implement them in the field for the smooth process and expected results. (4) Considerations in the follow-up scheme need to be designed by SNVT to respond to unforeseen events such as force majeure. (5) In connection with the tasks in the midst of a COVID-19 pandemic, SNVT or related agencies, it is necessary to consider policies to support the field process, especially for TFL as the frontline in BSPS. (6) Initiative action is highly needed by various layers, especially the field team who deal directly with different circumstances and situations in one place. 


\section{REFERENCES}

Direktorat Jenderal Perumahan, D. R. S. K. P. U. dan P. R. Pelaksanaan

Bantuan Stimulan Perumahan Swadaya Selama Masa Pandemik COVID19, Pub. L. No. Ditjen.PnP/-/2020/SOP/- (2020). Indonesia.

Ermalia, A. A. U. (2019). Daftar UMK Kabupaten-Kota Provinsi Bali 2020 | IDN

Times. Retrieved May 24, 2020, from

https://bali.idntimes.com/life/career/ayu-afria-ulita-ermalia/daftar-umkkabupaten-kota-provinsi-bali/1

Isbaniah, F., Kusumowardhani, D., Sitompul, P. A., Susilo, A., Setyawaty, V., Aryati, ... Setiadi, P. (2020). PEDOMAN PENCEGAHAN DAN PENGENDALIAN CORONAVIRUS DISEASE (COVID-19) REVISI KE-4.

(L. Aziza, A. Aqmarina, \& M. Ihsan, Eds.). Jakarta: Kementerian Kesehatan

RI Direktorat Jenderal Pencegahan dan Pengendalian Penyakit (P2P).

Juniartini, N. L. P. (2019). Tinjauan Penyaluran Dana BSPS di Desa Tusan, Kecamatan Banjarangkan, Kabupaten Klungkung. Bali Membangun Bali, 2(3), 161-172.

Juniartini, N. L. P.; I Wayan Juniartha; I Nyoman Anom Fajaraditya Setiawan. 2020. The Distribution Process of the Housing Stimulant Grants Program (BSPS) during COVID-19 Pandemic Situation in Muncan Village, Karangasem Regency. Dikutip dari:

http://ejournal.baliprov.go.id/index.php/jbmb/article/view/110.

Karangasem, B. K. (2019). Kecamatan Selat Dalam Angka 2019. Karangasem: Badan Pusat Statistik Kabupaten Karangasem.

Lingkungan, K. W. M. K. dan. (2001). Planet Kita Kesehatan Kita. (K. H., Ed.).

Yogyakarta: Gadjah Mada University Press.

Muncan, D. (2015). Desa Muncan - Kecamatan Selat - Kabupaten

Karangasem. Retrieved May 24, 2020, from

https://desamuncan1.wordpress.com/

Nadhira, A. M. (2020). Beragam Istilah Terkait Virus Corona dan COVID-19 Alodokter. Retrieved May 25, 2020, from 
https://www.alodokter.com/beragam-istilah-terkait-virus-corona-dan-covid19

Nasional, K. A. dan T. R. P. (2011). UNDANG-UNDANG NOMOR 1 TAHUN 2011. Retrieved May 22, 2020, from https://www.atrbpn.go.id/Publikasi/Peraturan-Perundangan/UndangUndang/undang-undang-nomor-1-tahun-2011-883

Noak, P. A. (2016). Kedudukan Dan Kewenangan Desa Adat Dan Desa Dinas di Bali Pasca Pemberlakuan UU Nomor 6 Tahun 2014 Tentang Desa Dalam Perspektif Administratif. In International Conference "Democracy for People” 2016 (p. 4). Semarang: UIN Walisongo.

Permana, I Putu Hendika. 2020. Analisis Media Online sebagai Sumber Informasi Wisatawan Australia dalam Mendapatkan Informasi Virus Corona di Bali. Jurnal Bali Membangun Bali, Volume 1, Nomor 2, Agustus 2020. Dikutip dari:

http://ejournal.baliprov.go.id/index.php/jbmb/article/view/111.

Pusat, P. (1992). UU No. 4 Tahun 1992 tentang Perumahan dan Permukiman [JDIH BPK RI]. Retrieved May 22, 2020, from https://peraturan.bpk.go.id/Home/Details/46596/uu-no-4-tahun-1992

Putri, G. S. (2020). Mengenal Gejala Virus Corona Baru Penyebab Covid-19. Retrieved May 25, 2020, from https://www.kompas.com/sains/read/2020/03/24/110100923/mengenalgejala-virus-corona-baru-penyebab-covid-19

Setiawan, I. N. A. F. (2020). Balinese Script In Tattoo Media Commodity In Denpasar Bali. ADI Journal on Recent Innovation (AJRI), 1(2), 98-106. https://doi.org/https://doi.org/10.34306/ajri.v1i2.29

Setiawan, I. N. A. F., \& Jayanegara, I. N. (2019). Sistem Tanda Visual Logo STMIK STIKOM Indonesia. Denpasar: STMIK STIKOM Indonesia.

Retrieved from https://play.google.com/store/books/details/I_Nyoman_Anom_Fajaraditya_ Setiawan_Sistem_Tanda_Vi?id=K2-9DwAAQBAJ 
Sugiyono. (2009). Metode Penelitian Kuantitatif, Kualitatif dan R\&D. Bandung: Alfabeta.

Suharmadi. (1985). Perumahan Sehat, Proyek Pengembangan Pendidikan Tenaga Kesehatan Departemen Kesehatan RI. Jakarta: Pusdiknakes.

SUYATRA, I. P. (n.d.). Pilkel Muncan Memanas, Petahana Kalah, Saksi Calon Lawan Dipukul. Retrieved May 29, 2020, from https://baliexpress.jawapos.com/read/2019/11/24/167254/pilkel-muncanmemanas-petahana-kalah-saksi-calon-lawan-dipukul.

Tim Editor. 2020. "Covid-19 Belum Berlalu, JBMB Harus Terus Berkembang", Jurnal Bali Membangun Bali, Volume 1, Nomor 2, Agustus 2020.

http://ejournal.baliprov.go.id/index.php/jbmb. 